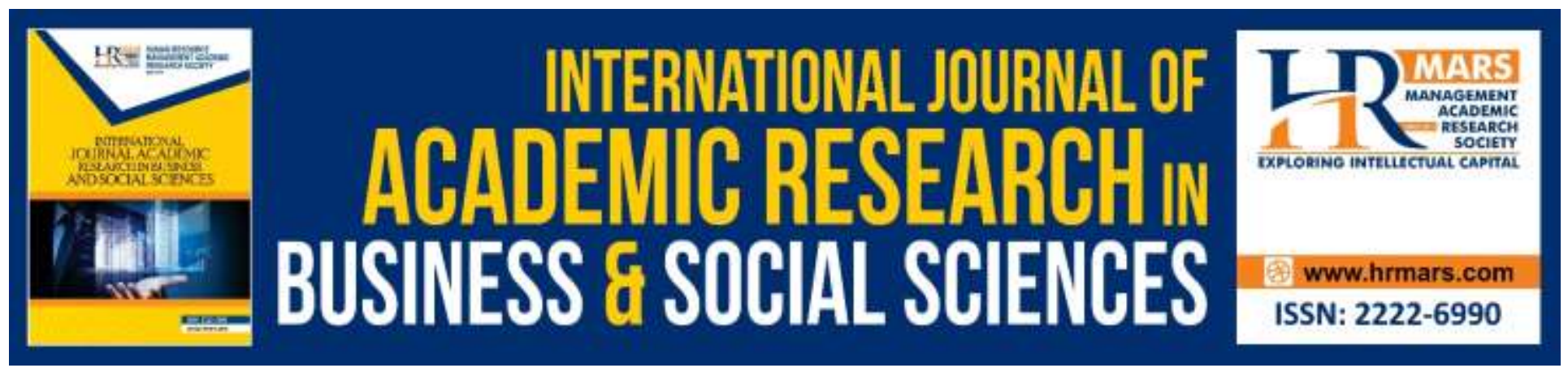

\title{
Soft Skills Among Hearing Impaired Graduates for Sustainability and Well-Being in Workplace
}

Yong Seh Sheh, Zaliza Hanapi, Ramlee Mustapha, Tee Tze Kiong

To Link this Article: http://dx.doi.org/10.6007/IJARBSS/v10-i5/7187

DOI:10.6007/IJARBSS/v10-i5/7187

Received: 01 March 2020, Revised: 05 April 2020, Accepted: 22 April 2020

Published Online: 09 May 2020

In-Text Citation: (Sheh et al., 2020)

To Cite this Article: Sheh, Y. S., Hanapi, Z., Mustapha, R., \& Kiong, T. T. (2020). Soft Skills Among Hearing Impaired Graduates for Sustainability and Well-Being in Workplace. International Journal of Academic Research in Business and Social Sciences, 10(5), 191-206.

\section{Copyright: (c) 2020 The Author(s)}

Published by Human Resource Management Academic Research Society (www.hrmars.com)

This article is published under the Creative Commons Attribution (CC BY 4.0) license. Anyone may reproduce, distribute, translate and create derivative works of this article (for both commercial and non-commercial purposes), subject to full attribution to the original publication and authors. The full terms of this license may be seen at: http://creativecommons.org/licences/by/4.0/legalcode

\section{Vol. 10, No. 5, 2020, Pg. 191 - 206}

Full Terms \& Conditions of access and use can be found at http://hrmars.com/index.php/pages/detail/publication-ethics 


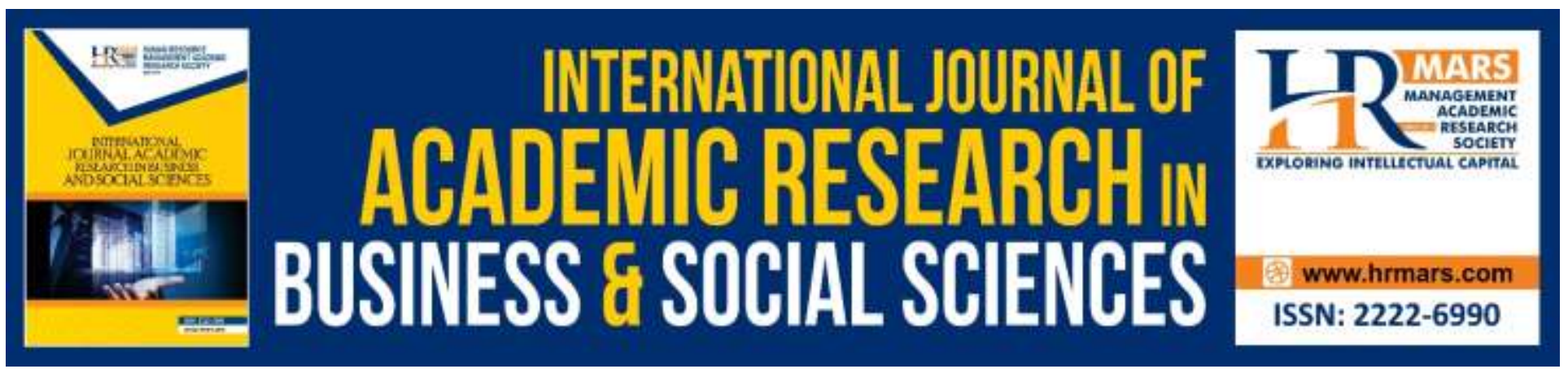

\title{
Soft Skills Among Hearing Impaired Graduates for Sustainability and Well-Being in Workplace
}

\author{
${ }^{1}$ Yong Seh Sheh, ${ }^{1}$ Zaliza Hanapi, ${ }^{1}$ Ramlee Mustapha, ${ }^{2}$ Tee Tze \\ Kiong \\ ${ }^{1}$ Sultan Idris Education University, Tanjong Malim, Perak, Malaysia, ${ }^{2}$ Universiti Tun Hussein Onn, \\ Malaysia
}

\begin{abstract}
Technical skill is not the only skill needed to secure an employment in the 21st century. Soft skills have become one of the basic needs nowadays and the most essential skill in industry for both common worker and hearing impaired worker. Graduates' unemployment issue showed a gap exists between academic excellent and equipped soft skills. Therefore, this article was written to determine the elements needed to sustain soft skills among hearing impaired graduates in order to ensure sustainability and well-being in workplace. The research uses meta-analysis, interview and fuzzy Delphi method to get consensus from 11 experts consisting of four specialist educators, four employers and three graduates in relation to hearing impaired community. The findings show that, the expert consensus agreement exceeds $75 \%$ with threshold (d) value $\leq 0.2$ and $\alpha$-cut $>0.5$. The elements of the soft skills for hearing impaired graduates were sorted and ranked as personal qualities, basic skills, resource and information skills, interpersonal skills, thinking skills, entrepreneurship skills and system and technology skills. For future studies, it is recommended to develop an instrument based on the elements of this study to measure soft skills of hearing impaired graduates. Meanwhile, educational institutions must work hand in hand with industry to strengthen the soft skills among future hearing impaired worker through industry training programme to produce more competitive workforce, sustainability and well-being in the workplace.
\end{abstract}

Keywords: Soft Skills, Hearing Impaired, Sustainability, Well-Being, Workplace.

\section{Introduction}

Human capital is an important human resource for the development of a country. To survive in the 21st century workforce, Technical and Vocational Education and Training (TVET) plays an important role in producing skilled and semi-skilled workers. Physical disability is not an unemployment reason for people with disabilities (PWD) as they are also part of the human resources that can contribute to national development. However, many PWD graduates are still unemployed (Samian, Md Ali, \& Buntat, 2013). Unemployment among PWDs are due to the lack of knowledge and skills required in the job market (Ang, 2012). To overcome this problem, TVET was introduced to PWDs to provide basic training in industry so that they could survive in the workplace that require 
skills. (Ministry of Education, 2012). TVET promises job market to PWDs and also serves as an agent in overcoming unemployment and poverty issues (Engr Amaechi, Orlu, Obed, \& Thomas, 2017).

As in Human Capital's Theory, a graduate is said to be eligible to work only if he/she gains a particular set of knowledge and skills with healthy and constructive personal values that may contribute to country development (Becker, 1975). The process of getting and sustaining jobs for PWDs is more complicated with more barriers. Despite having academic qualifications and knowledge in the field of training, a PWD will still face failure if he/she has no self confidence in the ability to perform a task (Ramli, 2010). Compared with hearing individuals, hearing impaired graduates have more difficulty making adjustments to face the challenges in the workplace (Feldman, 2004). Failure to adapt to the workplace environment causes many hearing impaired graduates to choose to withdraw from the working world. On the other hand, a strong soft skills may lead them to sustain in every job. Soft skills needed by hearing impaired graduates may differ from hearing graduates. Therefore, this study aims to find out the elements of soft skills among hearing impaired graduates.

\section{Soft Skills}

There are a great deal of literature about soft skills from all over the world and across various fields. Soft skills:

"are sets of skills, which will vary depending upon the context in which they are developed and applied."

(The Allen Consulting Group, 2006, p.13)

Soft skills among PWDs is rarely studied. Therefore, the skills must identify closely and related to hearing impaired. In this case, the soft skills that had been studied by previous researchers together with the points of interview with four stakeholders of hearing impaired community have been listed for further actions. Literature review and expert's interviews reveal the elements/aspects that dominate the soft skills among hearing impaired are as follows:

Table 1. Literature Analysis and Expert's Opinion on The Elements/Aspects of Soft Skills

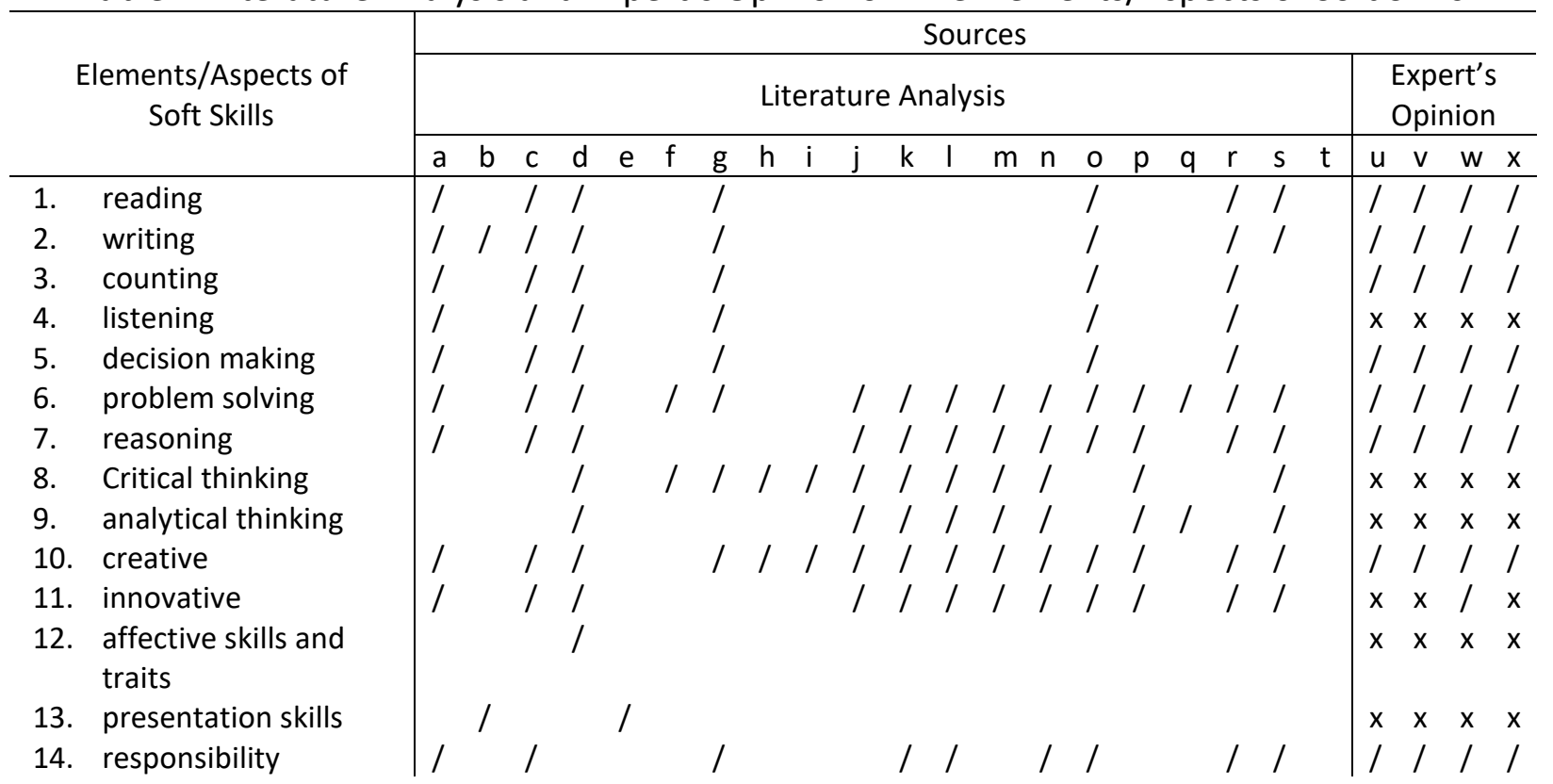


INTERNATIONAL JOURNAL OF ACADEMIC RESEARCH IN BUSINESS AND SOCIAL SCIENCES

Vol. 10, No. 5, May, 2020, E-ISSN: 2222-6990 @ 2020 HRMARS

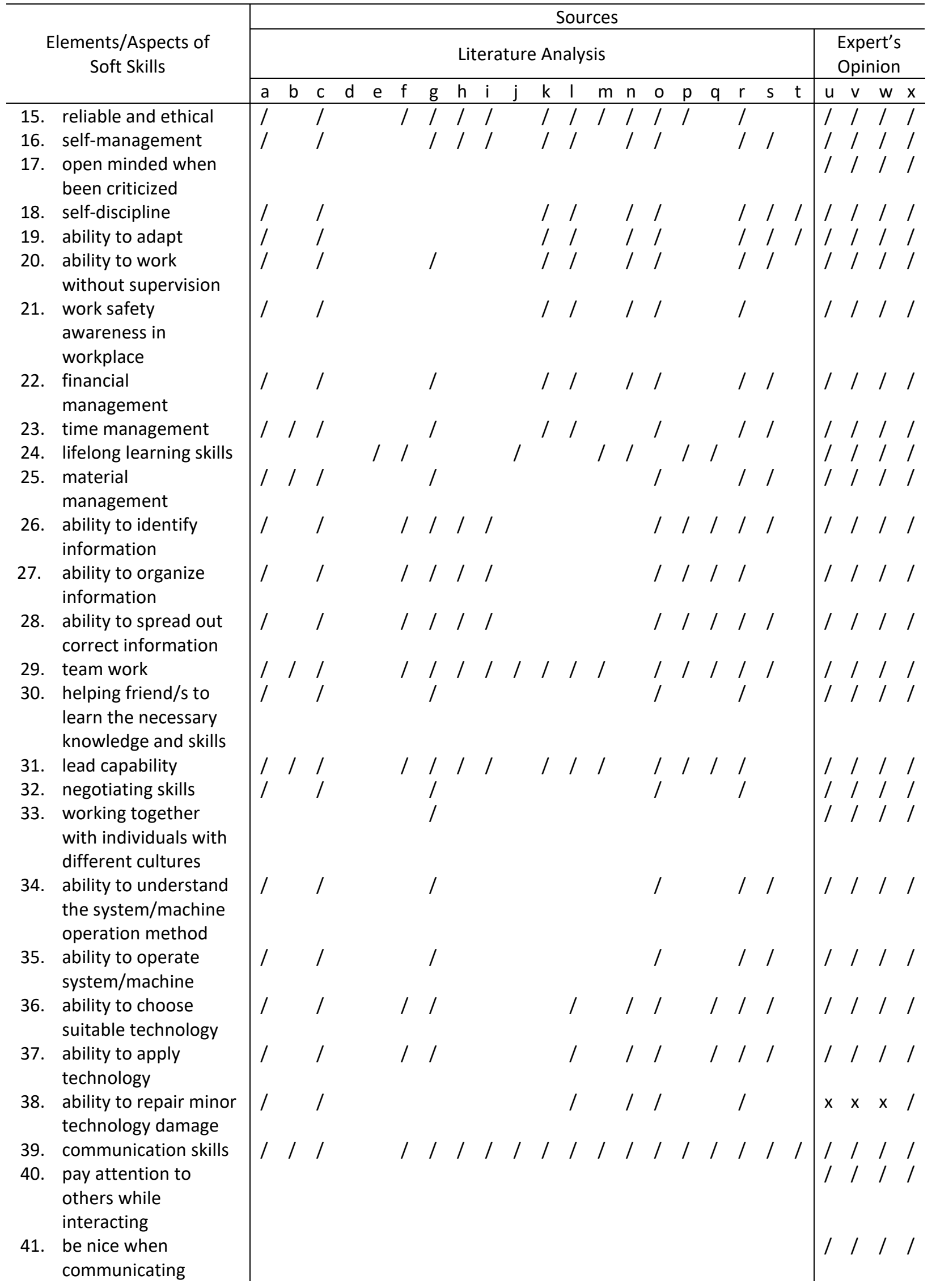


INTERNATIONAL JOURNAL OF ACADEMIC RESEARCH IN BUSINESS AND SOCIAL SCIENCES

Vol. 10, No. 5, May, 2020, E-ISSN: 2222-6990 @ 2020 HRMARS

\begin{tabular}{|c|c|c|c|c|c|c|c|c|c|c|c|c|c|c|c|c|c|c|c|c|c|c|c|}
\hline \multirow{3}{*}{\multicolumn{2}{|c|}{$\begin{array}{c}\text { Elements/Aspects of } \\
\text { Soft Skills }\end{array}$}} & \multicolumn{22}{|c|}{ Sources } \\
\hline & & \multicolumn{19}{|c|}{ Literature Analysis } & \multicolumn{3}{|c|}{$\begin{array}{l}\text { Expert's } \\
\text { Opinion }\end{array}$} \\
\hline & & $\mathrm{a}$ & $\mathrm{b}$ & $\mathrm{c}$ & $d$ & $\mathrm{e}$ & $f$ & $\mathrm{~g}$ & $\mathrm{~h}$ & $\mathrm{i}$ & $k$ & $\mathrm{I}$ & $\mathrm{m}$ & $\mathrm{n}$ & o & $p$ & $q$ & $r$ & $\mathrm{~s}$ & $\mathrm{t}$ & & v & $w$ \\
\hline 42. & $\begin{array}{l}\text { use simple sign } \\
\text { language/body } \\
\text { gesture/eyes contact } \\
\text { to communicate }\end{array}$ & & 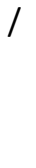 & & & & & & & & & & & & & & & & & & & / & / \\
\hline 43. & $\begin{array}{l}\text { prepared with writing } \\
\text { material to express } \\
\text { own thought if } \\
\text { hearing people } \\
\text { cannot understand }\end{array}$ & & / & & & & & & & & & & & & & & & & & & & / & / \\
\hline 44. & $\begin{array}{l}\text { social ability (join in } \\
\text { group of hearing } \\
\text { people) }\end{array}$ & / & / & / & & & / & & & & & & & & / & & & I & 7 & & & / & / \\
\hline 45. & $\begin{array}{l}\text { entrepreneurship } \\
\text { skills }\end{array}$ & & & & & & / & & / & / & & & l & & & & / & & & & & $x$ & $x$ \\
\hline
\end{tabular}

Indicator:

1. SCANS (1991)

2. Barnes (2017)

3. The Conference Board of Canada (2000)

4. Cotton (1993)

5. Harvey (2010)

6. Husain, et al. (2012)

7. Rosenberg, Heimler, \& Morote (2012)

8. Hanapi, et al. (2016)

9. Hanapi (2015)

10. Zaharim, et al. (2010)
11. Hanapi, \& Nordin (2014)

12. Ismail (2012)

13. Mohamad Zamri, \& Ahmad (2017)

14. Danial, Bakar, \& Mohamed (2014)

15. Monzaid, M. Said, \& Azman Hasan (2015)

16. Husain, et al. (2010)

17. Ahmad Ali, Othman, \& Ahmad (2017)

18. Ab Halim, et al. (2013)

19. Mohd Yusof, et al. (2017)

20. Mohd Zahari, et al. (2010)

Based on the analysis of literature search and expert's opinion on the elements/aspects of soft skills among hearing impaired graduates, the researchers have produced a new list of soft skills needed by hearing impaired graduates to obtain and sustain in workplace. The aspects being critical thinking, analytical thinking, affective skills and traits and presentation skills have been aborted due to disagreement from all stakeholders who were interviewed. The aspect listening is changed to interpreting as it is more relevant to hearing impaired community. Communication skills as element to four aspects of "pay attention to others while interacting", "be nice when communicating", "use simple sign language/body gesture/eyes contact to communicate" and "prepared with writing material to express own thoughts if hearing people cannot understand". The four aspects are referring to communication skills as well. Therefore, communication skills itself is not listed. Although aspect "innovation", "ability to repair minor technology damage" and "entrepreneurship skill" are not having consensus of stakeholder interviewed, but they are still included in the list that need to be tested. The new list of soft skills is then transformed into fuzzy Delphi questionnaire to test using fuzzy Delphi method. Figure 1 showed the conceptual framework of this study. 
INTERNATIONAL JOURNAL OF ACADEMIC RESEARCH IN BUSINESS AND SOCIAL SCIENCES Vol. 10, No. 5, May, 2020, E-ISSN: 2222-6990 @ 2020 HRMARS

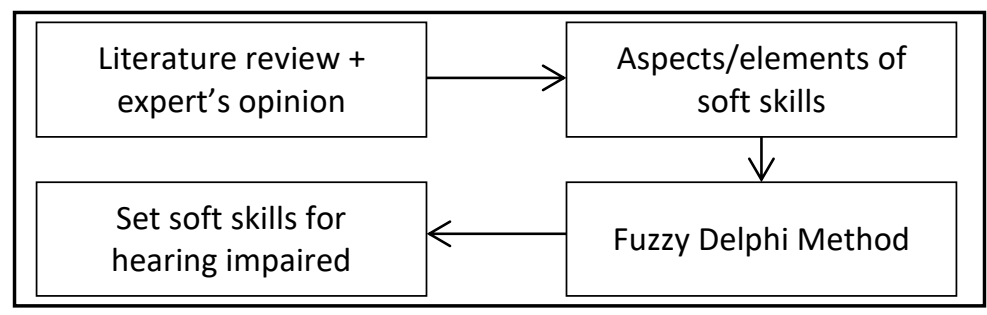

Figure 1: Conceptual framework

\section{The Purpose and Objective of The Study}

The purpose of this study was to obtain experts' consensus on the elements needed to sustain soft skills among TVET hearing impaired graduates with regards to sustain well-being in workplace.

(a) What is the consensus of experts on the elements of generic skills among TVET hearing impaired graduates?

\section{Methods}

"The Delphi method is well suited as a research instrument when there is incomplete knowledge about a problem." (Jafari, et al., 2008, p.291). Due to its problem of ambiguity, Chang, et al. (2000) introduce fuzzy Delphi method which is a combination method of Delphi classic and fuzzy set theory. This paper employed quantitative research design with fuzzy Delphi method as the main. Fuzzy Delphi using triangulation method in order to get statistical data to determine the suitability of the preselected item and data collected are reliable and trustable only one round (Kamarulzaman et al., 2015). Besides saving time and cost, the key purpose of using fuzzy Delphi method is to obtain the original reaction from the experts whereby the experts can fully express their opinions without any others influences. Each expert answers the questionnaire separately without any interaction.

Before analyzing using fuzzy Delphi method, researchers had gathered the elements of the soft skills among hearing impaired graduates through literature analysis of past studies and interviewed four main stakeholders consisting of society committee member, employer, educator and employee (hearing impaired graduate) in relation to hearing impaired community. After that, researchers developed a 7-points fuzzy scale questionnaire to distribute to 11 experts consisting of four specialist educators, three employers, three graduates and one society committee member. Then, the data collected was analyse using fuzzy Delphi method.

\section{Sampling}

Purposive sampling was adopted in this study to select the experts in the field. Purposive sampling also known as judgment sampling (Dolores, \& Tongco, 2007) involves researcher's consideration on the sample selection based on own knowledge and research needs. The success of Delphi research relies on two key aspects which are the number and the expertise of sample chosen (Powell, 2003). In this study, there were two groups of sampling. The first group of four experts selected were involved in interview sessions. They were society committee member, educator, employer and hearing impaired employee in relation to the hearing impaired community. The purpose of the interview was to gain more opinions from the stakeholders due to the lack of knowledge regarding hearing impaired community (Powell, 2003).

Hsu and Sandford (2007) stated that the suitable number of experts in fuzzy Delphi method research is between 10 to 20 experts. This is also confirmed by Cavalli and Ortolano (1984) that eight 
INTERNATIONAL JOURNAL OF ACADEMIC RESEARCH IN BUSINESS AND SOCIAL SCIENCES Vol. 10, No. 5, May, 2020, E-ISSN: 2222-6990 @ 2020 HRMARS

to 12 experts are sufficient if the selected experts are homogenous. Besides that, Philip (2000) also agreed that the sample needed in application of fuzzy Delphi method is between seven to 12 experts. Therefore, the second group of sampling in this study involved 11 experts made up of four specialist educators, three employers, three graduates and one society committee member (refer Table 2). To make sure the finding is reliable, it is important to select a panel of experts that are truly experts in the field for current situation and have the willingness to participate. Only those potential experts may contribute useful and up to date knowledge and perception on the real issue. In this study, the panel of experts must be homogenous based on the criteria (i) experience in the field of study at least 10 years, (ii) currently serving in hearing impaired community, and/or (iii) have industrial background.

Table 2: List of Experts in Fuzzy Delphi Method

\begin{tabular}{lll}
\hline Position & Expertise & Experience \\
\hline 1. Associate Professor & Special Education (Hearing Impaired) & $>20$ years \\
2. Associate Professor & Special Education (Hearing Impaired) & $>20$ years \\
3. Senior Lecturer & TVET and Special Education (Hearing Impaired) & $>10$ years \\
4. Polytechnic Lecturer & TVET and Special Education (Hearing Impaired) & $>10$ years \\
5. Employer & Hiring hearing impaired graduate as employee & $>10$ years \\
6. Employer & Hiring hearing impaired graduate as employee & $>10$ years \\
7. Employer & Hiring hearing impaired graduate as employee & $>10$ years \\
8. Graduate & Hearing impaired graduate & $>10$ years \\
9. Graduate & Hearing impaired graduate & $>10$ years \\
10. Graduate & Hearing impaired graduate & $>10$ years \\
11. Society Committee Member & Hearing impaired & $>28$ years \\
\hline
\end{tabular}

\section{Instrument}

A set of questionnaires related to soft skills among TVET hearing impaired graduates was adopted and adapted by the researchers based on the literature search and the expert views through interviews with four main stakeholders. This is agreed by Jamil, et al., (2014) that developing a questionnaire in fuzzy Delphi method can be done by literature review, individual interview and focus group interview. Besides, Skulmowski, Hartman and Krahn (2007) also stated that element build-up for a questionnaire by researcher can be done by researcher's own experience, pilot test and literature review. In connection to this, there was a total of eight elements with the explanation questionnaire that was developed. Using questionnaire in research is easier to collect data from wide range of places, save cost and time (Creswell, 2014). Questionnaire employ 7-points scale as the higher the scale, the more accurate the data will get (Jamil, et al., 2014). In Table 3, researchers put a scale of 1 to 7 instead of fuzzy scale value that confusing to make it easier to understand.

Table 3: Linguistic Variables for The Importance Weight of Criteria (Source: Jamil et al., 2014)

\begin{tabular}{ccc}
\hline Likert Scale & Linguistic variable & Fuzzy Scale \\
\hline 1 & Extremely Unimportant (EU) & $(0.0,0.0,0.1)$ \\
2 & Not Very Important (NV) & $(0.0,0.1,0.3)$ \\
3 & Not Important (NI) & $(0.1,0.3,0.5)$ \\
4 & Fair (F) & $(0.3,0.5,0.7)$ \\
5 & Important (I) & $(0.5,0.7,0.9)$ \\
6 & Very Important (VI) & $(0.7,0.9,1.0)$ \\
7 & Extremely Important (EI) & $(0.9,1.0,1.0)$ \\
\hline
\end{tabular}


INTERNATIONAL JOURNAL OF ACADEMIC RESEARCH IN BUSINESS AND SOCIAL SCIENCES

Vol. 10, No. 5, May, 2020, E-ISSN: 2222-6990 @ 2020 HRMARS

\section{Data Collection}

This paper implemented fuzzy Delphi steps to process data collection and analysis. Figure 2 below showed the overall process in detail from the beginning to the end.

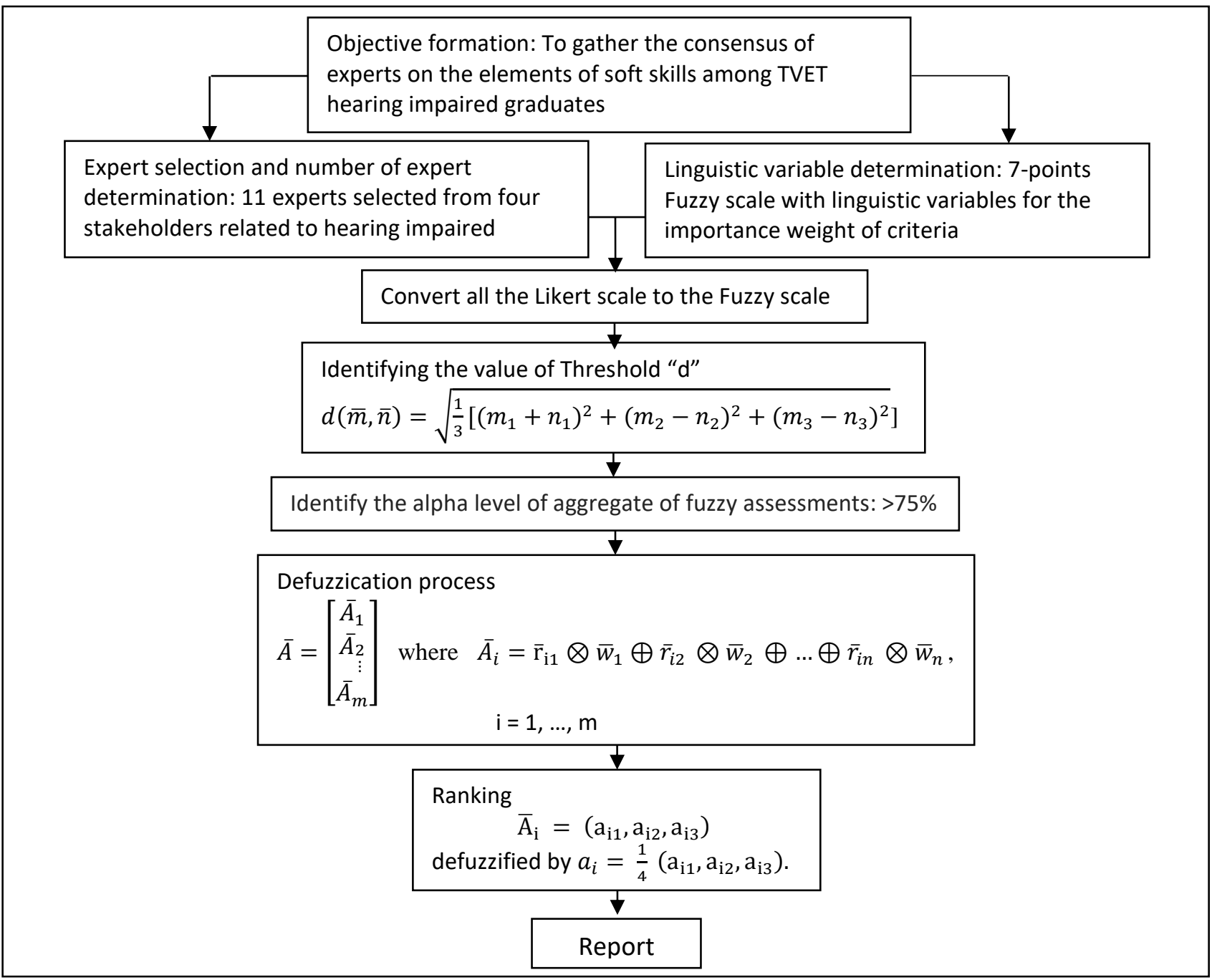

Figure 2. The process of data collection and analysis

\section{Findings}

Based on the analysis of literature and expert's interview (refer Table 4), researchers listed the elements/aspects of soft skills needed by TVET hearing impaired graduates in connection with obtaining and sustaining well-being in workplace with the result of both the literature analysis and interview with experts, researchers arranged the information gathered manually and came up with a list of soft skills' elements/aspects needed by hearing impaired graduates to obtain sustainability and well-being in workplace. Using all the elements/aspects researchers then develops a questionnaire to distribute to 11 experts. The data is then analysed using fuzzy Delphi method to get expert's consensus. The data that has been analyzed is presented in the form of tables according to the item to answer the objective of the study. Table 4 below showed the expert consensus on elements soft skills for TVET hearing impaired graduates in term of threshold value (d), percentage of expert's consensus (\%), defuzzication process, expert's consensus and ranking. 
INTERNATIONAL JOURNAL OF ACADEMIC RESEARCH IN BUSINESS AND SOCIAL SCIENCES Vol. 10, No. 5, May, 2020, E-ISSN: 2222-6990 @ 2020 HRMARS

Table 4: Expert Consensus on Elements Soft Skills

\begin{tabular}{|c|c|c|c|c|c|c|c|c|}
\hline \multirow[b]{2}{*}{ Item } & \multicolumn{2}{|c|}{ Triangular Fuzzy Numbers } & \multicolumn{4}{|c|}{ Defuzzification Process } & \multirow[b]{2}{*}{$\begin{array}{l}\text { Expert's } \\
\text { Consensus }\end{array}$} & \multirow[b]{2}{*}{ Ranking } \\
\hline & $\begin{array}{l}\text { Threshold } \\
\text { value, } d\end{array}$ & $\begin{array}{l}\text { Percentage of Expert's } \\
\text { Consensus (\%) }\end{array}$ & $\mathrm{m} 1$ & $\mathrm{~m} 2$ & m3 & $\begin{array}{l}\text { Average of Fuzzy } \\
\text { Number }\end{array}$ & & \\
\hline 1 & 0.10 & $100 \%$ & 0.72 & 0.89 & 0.98 & 0.86 & ACCEPTED & 12 \\
\hline 2 & 0.18 & $91 \%$ & 0.66 & 0.84 & 0.95 & 0.82 & ACCEPTED & 23 \\
\hline 3 & 0.17 & $91 \%$ & 0.70 & 0.86 & 0.95 & 0.84 & ACCEPTED & 18 \\
\hline 4 & 0.07 & $100 \%$ & 0.83 & 0.96 & 1.00 & 0.93 & ACCEPTED & 3 \\
\hline 5 & 0.18 & $82 \%$ & 0.68 & 0.85 & 0.95 & 0.83 & ACCEPTED & 20 \\
\hline 6 & 0.13 & $100 \%$ & 0.72 & 0.88 & 0.97 & 0.86 & ACCEPTED & 14 \\
\hline 7 & 0.16 & $91 \%$ & 0.66 & 0.85 & 0.95 & 0.82 & ACCEPTED & 22 \\
\hline 8 & 0.17 & $91 \%$ & 0.61 & 0.80 & 0.94 & 0.78 & ACCEPTED & 26 \\
\hline 9 & 0.12 & $91 \%$ & 0.57 & 0.76 & 0.93 & 0.75 & ACCEPTED & 28 \\
\hline 10 & 0.06 & $100 \%$ & 0.85 & 0.97 & 1.00 & 0.94 & ACCEPTED & 2 \\
\hline 11 & 0.10 & $91 \%$ & 0.79 & 0.94 & 0.99 & 0.91 & ACCEPTED & 4 \\
\hline 12 & 0.13 & $91 \%$ & 0.77 & 0.92 & 0.97 & 0.89 & ACCEPTED & 8 \\
\hline 13 & 0.10 & $100 \%$ & 0.77 & 0.93 & 0.99 & 0.90 & ACCEPTED & 6 \\
\hline 14 & 0.06 & $100 \%$ & 0.85 & 0.97 & 1.00 & 0.94 & ACCEPTED & 2 \\
\hline 15 & 0.06 & $100 \%$ & 0.85 & 0.97 & 1.00 & 0.94 & ACCEPTED & 2 \\
\hline 16 & 0.13 & $100 \%$ & 0.79 & 0.93 & 0.98 & 0.90 & ACCEPTED & 5 \\
\hline 17 & 0.05 & $100 \%$ & 0.86 & 0.98 & 1.00 & 0.95 & ACCEPTED & 1 \\
\hline 18 & 0.18 & $91 \%$ & 0.66 & 0.84 & 0.95 & 0.82 & ACCEPTED & 23 \\
\hline 19 & 0.12 & $100 \%$ & 0.75 & 0.91 & 0.98 & 0.88 & ACCEPTED & 9 \\
\hline 20 & 0.12 & $100 \%$ & 0.75 & 0.91 & 0.98 & 0.88 & ACCEPTED & 9 \\
\hline 21 & 0.16 & $91 \%$ & 0.59 & 0.78 & 0.93 & 0.77 & ACCEPTED & 27 \\
\hline 22 & 0.08 & $100 \%$ & 0.68 & 0.87 & 0.98 & 0.85 & ACCEPTED & 17 \\
\hline 23 & 0.16 & $91 \%$ & 0.63 & 0.82 & 0.95 & 0.80 & ACCEPTED & 24 \\
\hline 24 & 0.13 & $100 \%$ & 0.70 & 0.87 & 0.97 & 0.85 & ACCEPTED & 16 \\
\hline 25 & 0.10 & $100 \%$ & 0.77 & 0.93 & 0.99 & 0.90 & ACCEPTED & 6 \\
\hline 26 & 0.12 & $100 \%$ & 0.68 & 0.86 & 0.97 & 0.84 & ACCEPTED & 18 \\
\hline 27 & 0.19 & $91 \%$ & 0.68 & 0.85 & 0.95 & 0.82 & ACCEPTED & 21 \\
\hline 28 & 0.17 & $91 \%$ & 0.74 & 0.89 & 0.95 & 0.86 & ACCEPTED & 13 \\
\hline 29 & 0.16 & $91 \%$ & 0.75 & 0.90 & 0.96 & 0.87 & ACCEPTED & 11 \\
\hline 30 & 0.19 & $91 \%$ & 0.74 & 0.88 & 0.95 & 0.86 & ACCEPTED & 14 \\
\hline 31 & 0.15 & $91 \%$ & 0.72 & 0.88 & 0.96 & 0.85 & ACCEPTED & 15 \\
\hline 32 & 0.18 & $91 \%$ & 0.63 & 0.81 & 0.94 & 0.79 & ACCEPTED & 25 \\
\hline 33 & 0.13 & $100 \%$ & 0.77 & 0.92 & 0.98 & 0.89 & ACCEPTED & 7 \\
\hline 34 & 0.18 & $91 \%$ & 0.63 & 0.81 & 0.94 & 0.79 & ACCEPTED & 25 \\
\hline 35 & 0.09 & $100 \%$ & 0.75 & 0.92 & 0.99 & 0.89 & ACCEPTED & 8 \\
\hline 36 & 0.10 & $100 \%$ & 0.77 & 0.93 & 0.99 & 0.90 & ACCEPTED & 6 \\
\hline 37 & 0.19 & $91 \%$ & 0.70 & 0.86 & 0.95 & 0.84 & ACCEPTED & 19 \\
\hline 38 & 0.13 & $91 \%$ & 0.79 & 0.93 & 0.97 & 0.90 & ACCEPTED & 6 \\
\hline 39 & 0.15 & $100 \%$ & 0.75 & 0.90 & 0.97 & 0.88 & ACCEPTED & 10 \\
\hline 40 & 0.15 & $82 \%$ & 0.57 & 0.76 & 0.92 & 0.75 & ACCEPTED & 29 \\
\hline
\end{tabular}


INTERNATIONAL JOURNAL OF ACADEMIC RESEARCH IN BUSINESS AND SOCIAL SCIENCES Vol. 10, No. 5, May, 2020, E-ISSN: 2222-6990 @ 2020 HRMARS

Based on the result, those items showed threshold value, $d \leq 0.2$ (Cheng, \& Lin, 2002), percentage of expert's consensus $\geq 75 \%$ (Tang, \& Wu, 2010) and alpha value-cut exceed 0.5 (Bodjanova, 2006) were retained. That means all items that reached expert's agreement would to be accepted as aspect or element for soft skills among TVET hearing impaired graduates. The 40 accepted items resulting from the fuzzy Delphi method were ranked in orderly according to the eight elements that recommended by experts are shown in Table 5.

Table 5: Elements, Aspects and Ranking of Soft Skills for TVET Hearing Impaired

\begin{tabular}{|c|c|c|c|}
\hline No. & Elements & Aspects & Ranking \\
\hline \multirow[t]{11}{*}{1} & Personal qualities & responsibility & 2 \\
\hline & & reliable and ethical & 4 \\
\hline & & self-management & 8 \\
\hline & & open minded when been criticized & 6 \\
\hline & & self-discipline & 2 \\
\hline & & ability to adapt to (environment, work, community) & 2 \\
\hline & & ability to work without supervision & 5 \\
\hline & & work safety awareness in workplace & 1 \\
\hline & & financial management & 23 \\
\hline & & time management & 9 \\
\hline & & lifelong learning skills & 9 \\
\hline \multirow[t]{4}{*}{2} & Communication & pay attention to others while interacting & 8 \\
\hline & skills & be nice when communicating & 6 \\
\hline & & use simple sign language/body gesture/eyes contact to communicate & 19 \\
\hline & & $\begin{array}{l}\text { prepared with writing material to express own thought if hearing people } \\
\text { cannot understand }\end{array}$ & 6 \\
\hline \multirow[t]{4}{*}{3} & Basic skills & reading & 12 \\
\hline & & writing & 23 \\
\hline & & counting & 18 \\
\hline & & interpreting & 3 \\
\hline \multirow[t]{4}{*}{4} & Resource and & material management & 27 \\
\hline & information skills & ability to identify information & 17 \\
\hline & & ability to organize information & 24 \\
\hline & & ability to spread out correct information to others & 16 \\
\hline \multirow[t]{6}{*}{5} & Interpersonal & team work & 6 \\
\hline & skills & helping friend/s to learn the necessary knowledge and skills & 18 \\
\hline & & lead capability to a duty & 21 \\
\hline & & negotiating skills & 13 \\
\hline & & working together with individuals with different cultures & 11 \\
\hline & & social ability & 10 \\
\hline \multirow[t]{5}{*}{6} & Thinking skills & decision making & 20 \\
\hline & & problem solving & 14 \\
\hline & & reasoning & 22 \\
\hline & & creative & 26 \\
\hline & & innovative & 28 \\
\hline 7 & Entrepreneurship & capacity and willingness to develop, organize and manage a business & 29 \\
\hline \multirow[t]{5}{*}{8} & System and & ability to understand the system/machine operation method & 14 \\
\hline & technology skills & ability to operate system/machine & 15 \\
\hline & & ability to choose suitable technology & 25 \\
\hline & & ability to apply technology & 7 \\
\hline & & ability to repair minor technology damage & 25 \\
\hline
\end{tabular}


INTERNATIONAL JOURNAL OF ACADEMIC RESEARCH IN BUSINESS AND SOCIAL SCIENCES Vol. 10, No. 5, May, 2020, E-ISSN: 2222-6990 @ 2020 HRMARS

Based on Table 5, experts agreed that personal qualities of TVET hearing impaired graduates are most important. Of the 11 aspects, "work safety awareness in workplace" is in the first ranking with $d=0.05$, percentage of expert's consensus $=100 \%$ and $\alpha=0.95$. Followed by "responsibility", "selfdiscipline" and "ability to adapt". Aspect "financial management" in personal qualities is found to be less important. The second important element of soft skills is communication skills. Of the four aspects tested, "be nice when communicating" and "prepared with writing material to express own thought if hearing people cannot understand" are more important than "pay attention to others while interacting" followed by "use simple sign language/body gesture/eyes contact to communicate". The third important element is basic skills which consists of aspects reading, writing, counting and interpreting. Of the four aspects, experts pointed out "interpreting" as the most important skill. The subsequence important elements are resource and information skills, interpersonal skills, and thinking skills. The less important elements are entrepreneurship skills and system and technology skills.

\section{Discussions}

The results of the study as a whole found that there is an expert consensus on the elements of soft skills among TVET hearing impaired graduates. Results demonstrated that the most important soft skills among hearing impaired graduates by ranking are personal qualities, followed by, basic skills, resource and information skills, interpersonal skills, thinking skills, entrepreneurship skills and system and technology skills. The findings are consistent with the findings of Ab Halim, et al. (2013) in which the three most important soft skills are personal qualities, basic skills and interpersonal skills. Similarly, hearing impaired graduates themselves, declare that they are weak in soft skills such as basic skills, communication skills, and interpersonal skills as well as social skills (Hanapi et al., 2018). However, the results by Ismail (2012) found that the most significant soft skills are decision-making and problem solving skills followed by communication and interpersonal skills. This shows a slight difference between ordinary worker and hearing impaired worker.

Employers find it hard to accept disabled people not because of the disability they have but the personality they possess (Hanapi et al., 2018). All experts agree that the personal qualities of a hearing impaired graduates is the most important element with 11 aspects. This is in line with the views of Ahmad, Ali and Hamzah (2011). Besides, Mohd Yusof et al. (2017) found hearing impaired individuals are encounter self-discipline problems and difficult to maintain in their work. This is also the aspect that is emphasized by experts during interview. As long as the hearing impaired workers are equipped with high self-discipline, they will be able to self-adjust to be successful in future. Therefore, hearing impaired graduates must pay more attention to improving their personal qualities as a worker in order to make themselves more valuable in the job market (Hamid, 2012).

The second important element of soft skills is communication skills. For ordinary worker, there will be less issue as they can hear as well as speak using languages. But hearing impaired worker who cannot hear at all or some maybe partial in hearing, will need other than verbally languages such as sign language, body gesture or written text to help them express their thought. Although the employers feel that communication is not a barrier to hearing impaired individuals to succeed (Mohd Yusof et al., 2017), but still communication is the first problem that comes into mind when dealing with hearing impaired. Job Outlook 2019 also found communication skills is one of top four most essential skills rated by employers (National Association of Colleges and Employers, 2018). 
Basic skills for most past studies is the most important skills or is highly ranked (Ab Halim, et al., 2013) which is also the result of this study where it is in the third ranking. Basic skills for ordinary worker are slightly different compared to hearing impaired worker. The aspect "listening" has been modified to "interpreting" based on expert's opinion. It so happens, this aspect turns up to be the most significant aspect in basic skills. Sometimes, employers worry instructions are not being passed on because the hearing impaired worker lacks interpreting skills.

Resource and information skills are ranked number four, followed by interpersonal skills. Lacking interpersonal skills is said to be the cause of graduates' failure to even get a job. Based on the survey of PEW Research Center (2016), half of US's employees agreed that interpersonal skills play a supremely important role in leading them into the workforce, performing in jobs or changing job. After interpersonal skills, there are thinking skills and entrepreneurship skills. Most of the experts interviewed do not agree with this skills being included in soft skills as entrepreneurship skills focuses on the running of business, not employment.

In the new era of technology, system and technology skills are surprisingly rated as less important skills. Maybe that's because of the rapid change of technology necessitating employees to be willing to learn the new technology rather than remaining with what they have learnt in institutions. Nowadays, with just one button, the system will run as it's programmed. This is most likely on technical skills which is more specific to the field of industry that one individual is involved in. Therefore, this skill is not as important as other skills. Rosenberg, Heimler and Morote (2012) also found system and technology skills less important to pursue job performance because it is less emphasized by the institution. Besides, employers deemed that system and technology's rapid change necessitates continual acquirement of new knowledge and learning abilities.

In conclusion, employers are now more concerned about soft skills as a key requirement for hiring, followed by technical skills and academic achievements in the process of achieving success in the job market (Abdul Hamid, Islam, \& Abd Manaf, 2014). But, most hearing impaired graduates are still unable to meet the employer's expectations, especially in terms of soft skills. Based on the results compiled, it can be used to develop module to increase soft skills according the significance of the soft skills needed by hearing impaired graduates. Meanwhile, educational institution must work hand in hand with industry to strengthen the soft skills among future hearing impaired worker through industry training programme to produce more competitive workforce, sustainability and well-being in the workplace. A simple model has been drawn in Figure 3 to demonstrate the overall soft skills needed for employment among hearing impaired worker. 


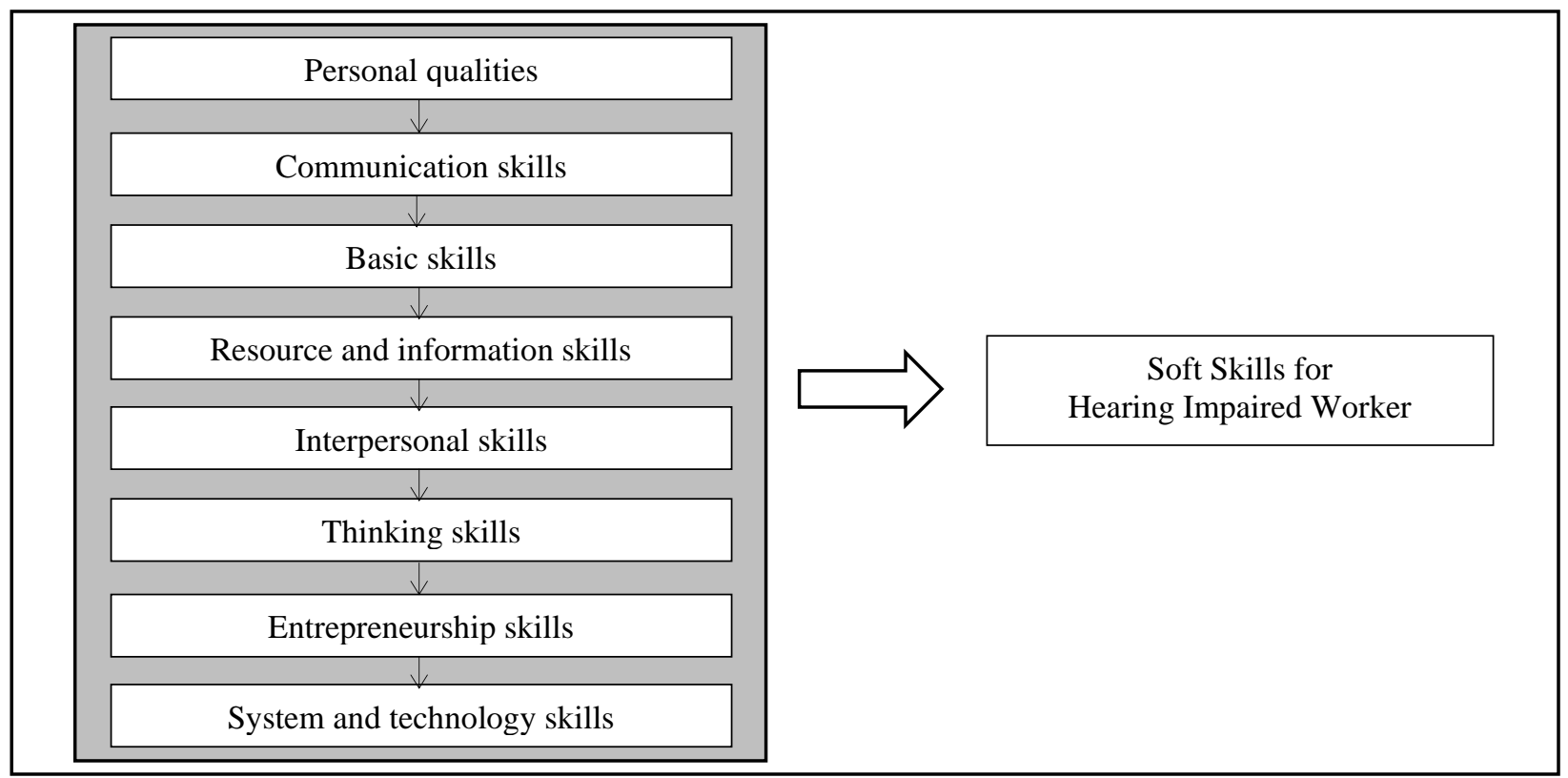

Figure 3. Soft skills for hearing impaired worker

\section{Conclusion}

Soft skills need to sustain employment. A hearing impaired graduate's soft skills are probably same as hearing graduates. They have lost their hearing but seem to be as normal as hearing people. The most important thing for them is to understand and be understood. Someone who is hearing impaired and wish to succeed in the job market needs to equip himself/herself with the value of marketability such as soft skills (Eby, Butts, \& Lockwood, 2003). The study found that in the context of hearing impaired graduates, personal qualities and communication skills play a significant role in their employment. This is followed by basic skills, resource and information skills, interpersonal skills, thinking skills, entrepreneurship skills and system and technology skills.

The findings suggested a framework of Soft Skills for Hearing Impaired. This framework combined with different view from stakeholders that can be explained by aspects inclusion. It may help hearing impaired graduates to establish self-perception of soft skills needed by employer before entering to the work place. However, a new assessment tool needs to be formulated to achieve more accurate evaluation of this community. This study has provided references to develop an instrument on soft skills of TVET hearing impaired graduates using the elements with the aspects suggested. However, this effort is left to the next researcher in the future.

\section{Acknowledgement}

The researchers appreciate all the experts participated in this study for their useful suggestions, advices and encouragement.

\section{Corresponding Author}

Yong Seh Sheh

Faculty of Technical and Vocational, Universiti Pendidikan Sultan Idris, 35900 Tanjong Malim, Perak, Malaysia.

Email: yongsehsheh@gmail.com 
INTERNATIONAL JOURNAL OF ACADEMIC RESEARCH IN BUSINESS AND SOCIAL SCIENCES

Vol. 10, No. 5, May, 2020, E-ISSN: 2222-6990 @ 2020 HRMARS

\section{References}

Abdul Hamid, M. S., Islam, R., \& Abd Manaf, N. H. (2014). Employability skills development approaches: An application of the analytic network process. Asian Academy of Management Journal, 19(1), 93-111. http://web.usm.my

Ab Halim, F., Bakar, A. R., Hamzah, R., \& Rashid, M. A. (2013). Employability silks of technical and vocational students with hearing impairments: Employers' perspectives. Journal of Technical Education and Training, 5(2), 65-74. https://publisher.uthm.edu.my

Ali, A. F. M., Othman, A. R., \& Ahmad, N. (2017). Graduate's marketable skills: An empirikal investigation of its effect on perceived marketability of Yemeni graduates in the Arab Gulf States. Asian Journal of Science and Technology, 8(11), 6497-6509. https://www.journalajst.com

Barnes, L. (2017). Employment and employability: The experiences and perceptions of deaf graduates. A thesis for the Degree of Professional Doctorate in Education. University of Central Lancashire. https://www.clok.uclan.ac.uk

Becker, G. S. (1975). Investment in human capital: Effects on earnings. A theoretical and empirical analysis, with special reference to education (2nd ed.), 13-44 ISBN: 0-226-04109-3. https://www.nber.org/books/beck75-1

Bodjanova, S. (2006). Median alpha-levels of a fuzzy number. Fuzzy Sets and Systems, 157(7), 879891. https://doi:10.1016/j.fss.2005.10.015

Cavalli-Sforza, V., \& Ortolano, L. (1984). Delphi forecasts of land use-transportation interactions. Journal of Transportation Engineering, 110(3), 324-339. https://doi:10.1061/(ASCE)0733947X(1984)110:3(324)

Chang, P. T., Huang, L. C., \& Lin, H. J. (2000). The fuzzy Delphi via fuzzy statistics and membership function fitting and an application to human resources, Fuzzy Sets and Systems, 112, 511-520. https://elsevier.com/locate/fss

Cheng, C. H., \& Lin, Y. (2002). Evaluating the best main battle tank using fuzzy decision theory with linguistic criteria evaluation. European Journal of operational research, 142(1), 174-186. https://doi:10.1016/S0377-2217(01)00280-6

Cotton, K. (1993). Developing employability skills. School Improvement Research Series. Northwest Regional Educational Laboratory. https://educationnorthwest.org

Creswell, J. W. (2014). Research design: qualitative, quantitative and mixed methods approaches (4th ed.) Sage Publication, Inc. http://englishlangkan.com

Danial, J., Bakar, A. R., \& Mohamed, S. (2014). Factors influencing the acquisition of employability skills by students of selected technical secondary school in Malaysia. International Education Studies, 7(2). https://doi:10.5539/ies.v7n2p117

Dolores, M., \& Tongco, C. (2007). Purposive sampling as a tool for informant selection. Ethnobotany Research \& Applications, 5, 147-158. http://hdl.handle.net/10125/227

Eby, L., Butts, M., \& Lockwood, A. (2003). Predictors of success in the era of the boundaryless career. Journal of Organizational Behavior, 24, 689-708. https://doi.org/10.1002/job.214

Engr Amaechi, O. J., Orlu, I., Obed, O. O., \& Thomas, C. G. (2017). The role of technical and vocational education and training (TVET) as agents of tackling unemployment and poverty amongst technical college graduates in rivers state. World Journal of Engineering Research and Technology, 3(2), 17-30. http://www.wjert.org 
INTERNATIONAL JOURNAL OF ACADEMIC RESEARCH IN BUSINESS AND SOCIAL SCIENCES

Vol. 10, No. 5, May, 2020, E-ISSN: 2222-6990 @ 2020 HRMARS

Feldman, D. C. (2004). The role of physical disabilities in early career: Vocational choice, the schoolto-work transition and becoming established. Human Resource Management Rev., 14, 247-274. https://doi.org/10.1016/j.hrmr.2004.06.002

Hamid, N. H. (2012). Aspirasi kerjaya dalam kalangan pelajar bermasalah pendengaran di politeknik. Tesis Master. Universiti Tun Hussein Onn Malaysia. http://eprints.uthm.edu.my

Hanapi, Z. (2015). Kesepadanan latihan terhadap pekerjaan dalam kalangan graduan kejuruteraan elektrik di kolej komuniti. Tesis Doktor falsafah dalam Pendidikan. Universiti Teknologi Malaysia.

Hanapi, Z., Kamis, A., Tee T. K., \& Hanapi, M. H. (2016). Jurang integrasi kemahiran employabiliti di Malaysia: Satu kajian empirikal graduan kejuruteraan kolej komuniti. Geografia Online Malaysian Journal of Society and Space, 12(3), 145-1530. http://ejournal.ukm.my

Hanapi, Z., \& Nordin, M. S. (2014). Unemployment among Malaysia graduates: Graduates' attributes, lecturers' competency and quality of education. International Conference on Educational Psychology. Procedia - Social and Behavioral Sciences, 112: 1056-1063. https://doi: 10.1016/j.sbspro.2014.01.1269

Hanapi, Z., Yong, S. S., Safiee, Z., \& Tee, T. K. (2018). Tinjauan awal keperluan kajian kebolehpasaran graduan OKU bermasalah pendengaran. Online Journal for TVET Practitioners, 3(2). http://active.uthm.edu.my/ejournal

Harvey, L. (2010). Defining and measuring employability. Quality in Higher Education, 7(2), 97-109. https://doi.org/10.1080/13538320120059990

Hsu, C., \& Sandford, B. (2007). The Delphi technique: making sense of consensus. Practical Assessment, Research \& Evaluation, 12(10), 1-8. https://pareonline.net

Husain, M. Y., Mokhtar, S. B., Abdul Kamil, A., \& Mustapha, R. (2010) Kemahiran insaniah dalam kalangan pelajar kejuruteraan elektrik Politeknik Sultan Azlan Shah. The Regional Seminar on Sciences, Technology and Social Sciences. https://www.researchgate.net

Husain, M. Y., Mustapha, R., A. Malik, S., \& Mokhtar, S. B. (2012). Measurement model of employability skills using confirmatory factor analysis. 4th Regional Conference on Engineering Education and Research in Higher Education. http://tree.utm.my

Ismail, M. H. (2012). Kajian mengenai kebolehpasaran siswazah di Malaysia: Tinjauan dari perspektif majikan. Prosiding PERKEM VII (2), 906-913. http://www.ukm.my

Jafari, A., Jafarian, M., Zareei, A., \& Zaerpour, F. (2008). Using fuzzy Delphi method in maintenance strategy selection problem. Journal of Uncertain Systems, 2(4), 289-298. https://www.jus.org.uk

Jamil, R., Siraj, S., Hussin, Z., Nurulrabihah, \& Arifin, M. (2014). Pengenalan asas kaedah fuzzy Delphi dalam penyelidikan dan pembangunan. Penerbit Minda Intelek.

Kamarulzaman, N., Jomhari, N., Raus, M. N., \& Yusoff, M. Z. (2015). Applying the fuzzy Delphi method to analyze the user requirement for user centered design process in order to create learning applications. Indian Journal of Science and Technology, 8(32). https://doi: 10.17485/ijst/2015/v8i32/92146

Ministry of Education. (2012). Laporan awal Pelan Pembangunan Pendidikan Malaysia 2013-2015. https://www.moe.gov.my/

Zamri, M. E., \& Ahmad, N. (2017). Kajian terhadap kebolehpasaran graduan Diploma Kejuruteraan Perkhidmatan Bangunan, Politeknik Sultan Azlan Shah. eProceeding National Innovation and Invention Competition Through Exhibition. https://upikpolimas.edu.my 
INTERNATIONAL JOURNAL OF ACADEMIC RESEARCH IN BUSINESS AND SOCIAL SCIENCES

Vol. 10, No. 5, May, 2020, E-ISSN: 2222-6990 @ 2020 HRMARS

Yusof, M., Yasin, M. H., Hashim, S. H., \& Itam, A. M. (2017). Transition programme and barriers to participating in the employment sector among hearing impaired students in Malaysia. International Conference on Special Education in Southeast Asia Region (7th series). http://www.pertanika.upm.edu.my

Zahari, M. S., Yusoff, Mat. N., Jamaluddin, M. R., Radzi, M. S., \& Othman, Z. (2010). The employability of the hearing impaired graduates in Malaysia hospitality industry. World Applied Sciences Journal 10 (Special Issue of Tourism \& Hospitality), 126-135. https://pdfs.semanticscholar.org

Monzaid, E., M. Said, S., \& Hasan, A. (2015). Instrumen kemahiran employabiliti pelajar Diploma Teknologi Perindustrian Komputer Rangkaian di ILTM. Journal of Global Business and Social Entrepreneurship, 1(2), 28-34. http://gbse.com.my

National Association of Colleges and Employers. (2018). NACE research report: Job Outlook 2019. http://www.naceweb.org

Pew Research Center. (2016). The state of American jobs: How the shifting economic landscape is reshaping work and society and affecting the way people think about the skills and training they need to get ahead. http://www.pewresearch.org

Powell, C. (2003). The Delphi technique: myths and realities. Journal of Advanced Nursing, 41(4), 376382. https://doi: 10.1046/j.1365-2648.2003.02537.x

Ramli, J. (2010). Pengertian konsep kendiri. Penerbit Universiti Teknologi Malaysia. http://eprints.utm.my

Rosenberg, S., Heimler, R., \& Morote, E. (2012). Basic employability skills: A triangular design $\begin{array}{llll}\text { approach. Journal of Education }+ \text { Training, } & \text { 54(1), }\end{array}$ https://doi.org/10.1108/00400911211198869

Samian, S. S., Ali, Md. K., \& Buntat, Y. (2013). Persepsi majikan terhadap pekerja orang kurang upaya (OKU) dalam organisasi di negeri Johor. 2nd International Seminar on Quality and Affordable Education. https://educ.utm.my

Secretary's Commission on Achieving Necessary Skill (SCANS, 1991). What work requires of schools. A SCANS report for America 2000. U. S. Department of Labor. https://files.eric.ed.gov

Tang, C. W., \& Wu. C. T. (2010). Obtaining a picture of undergraduate education quality: A voice from inside the university. Higher Education, 60, 269-286. https://www.ingentaconnect.com

The Allen Consulting Group. (2006). Assessment and reporting of employability skills embedded in training packages. Report to the Department of Education, Science and Training, Melbourne. https://www.ncver.edu.au

The Conference Board of Canada. (2000). Employability skills. https://www.conferenceboard.ca

Zaharim, A., Md Yusoff, Y., Mohamed, A., Omar, M. Z., Muhamad, N., \& Mustapha, R. (2010). Practical framework of employability skills for engineering graduate in Malaysia. IEEE EDUCON Education Engineering. http://www.ieec.u 